\title{
Corrigendum: Trends and Inequalities in Unplanned Pregnancy in Three Population-Based Birth Cohorts in Pelotas, Brazil
}

\author{
Laísa Rodrigues Moreira ${ }^{1 *}$, Fernanda Ewerling ${ }^{1,2}$, Iná S. dos Santos ${ }^{1}$, \\ Fernando César Wehrmeister ${ }^{1,2}$, Alicia Matijasevich ${ }^{1,3}$, Aluisio J. D. Barros ${ }^{1,2}$, \\ Ana M. B. Menezes ${ }^{1}$, Helen Gonçalves ${ }^{1}$, Joseph Murray ${ }^{1}$, Marlos R. Domingues ${ }^{1}$ and \\ Mariângela Freitas Silveira ${ }^{1}$
}

${ }^{1}$ Postgraduate Program in Epidemiology, Federal University of Pelotas, Pelotas, Brazil, ${ }^{2}$ International Center for Equity in Health, Federal University of Pelotas, Pelotas, Brazil, ${ }^{3}$ Department of Preventive Medicine, Faculty of Medicine FMUSP, University of São Paulo, São Paulo, Brazil

Keywords: unplanned pregnancy, family planning, reproductive health, socioeconomic factors, health inequalities

\section{A Corrigendum on}

\section{OPEN ACCESS}

Edited and reviewed by: Nino Kuenzli, Swiss Tropical and Public Health Institute (Swiss TPH), Switzerland

*Correspondence: Laísa Rodrigues Moreira laisa.moreira.psi@gmail.com

Received: 20 May 2021 Accepted: 28 May 2021 Published: 19 August 2021

Citation:

Moreira $L R$, Ewerling $F$, dos Santos IS,

Wehrmeister FC, Matijasevich A, Barros AJ D, Menezes AMB,

Gonçalves H, Murray J, Domingues MR and Silveira MF (2021) Corrigendum: Trends and Inequalities in Unplanned Pregnancy in Three Population-Based Birth Cohorts in

Pelotas, Brazil. Int J Public Health 66:1604257. doi: 10.3389/ijph.2021.1604257
Trends and Inequalities in Unplanned Pregnancy in Three Population-Based Birth Cohorts in Pelotas, Brazil

by Moreira, L., Ewerling, F., dos Santos, I. S., Wehrmeister, F. C., Matijasevich, A., Barros, A. J. D., Menezes, A. M. B., Gonçalves, H., Murray, J., Domingues, M. R., Silveira, M. F. (2020). Int. J. Public Health. 10:1505. doi: 10.1007/s00038-020-01505-0

In the original article, there were errors. A correction has been made to:

The legend in Figure $\mathbf{1}$ is inverted. The darker dots, that generally have lower prevalence of unplanned pregnancy, represent the women with higher family income; and the lighter dots represent those with lower family income. Unfortunately, this mistake misleads the interpretation of the figure. This error occurred during the final step of the Editorial process, when the authors replaced the color figure with a black and white version.

Also, in the presentation of the results of Table 3, a minus sign is wrongly placed. Where it reads: "In 1993, the SII was-14.96, i.e., the prevalence of the outcome was-14.96 percentage points higher among the poorest mothers than among the richest mothers", it should actually say "In 1993, the SII was-14.96, i.e., the prevalence of the outcome was 14.96 percentage points higher among the poorest mothers than among the richest mothers".

I apologize for these mistakes on behalf of all co-authors.

Copyright (C) 2021 Moreira, Ewerling, dos Santos, Wehrmeister, Matijasevich, Barros, Menezes, Gonçalves, Murray, Domingues and Silveira. This is an open-access article distributed under the terms of the Creative Commons Attribution License (CC BY). The use, distribution or reproduction in other forums is permitted, provided the original author(s) and the copyright owner(s) are credited and that the original publication in this journal is cited, in accordance with accepted academic practice. No use, distribution or reproduction is permitted which does not comply with these terms. 


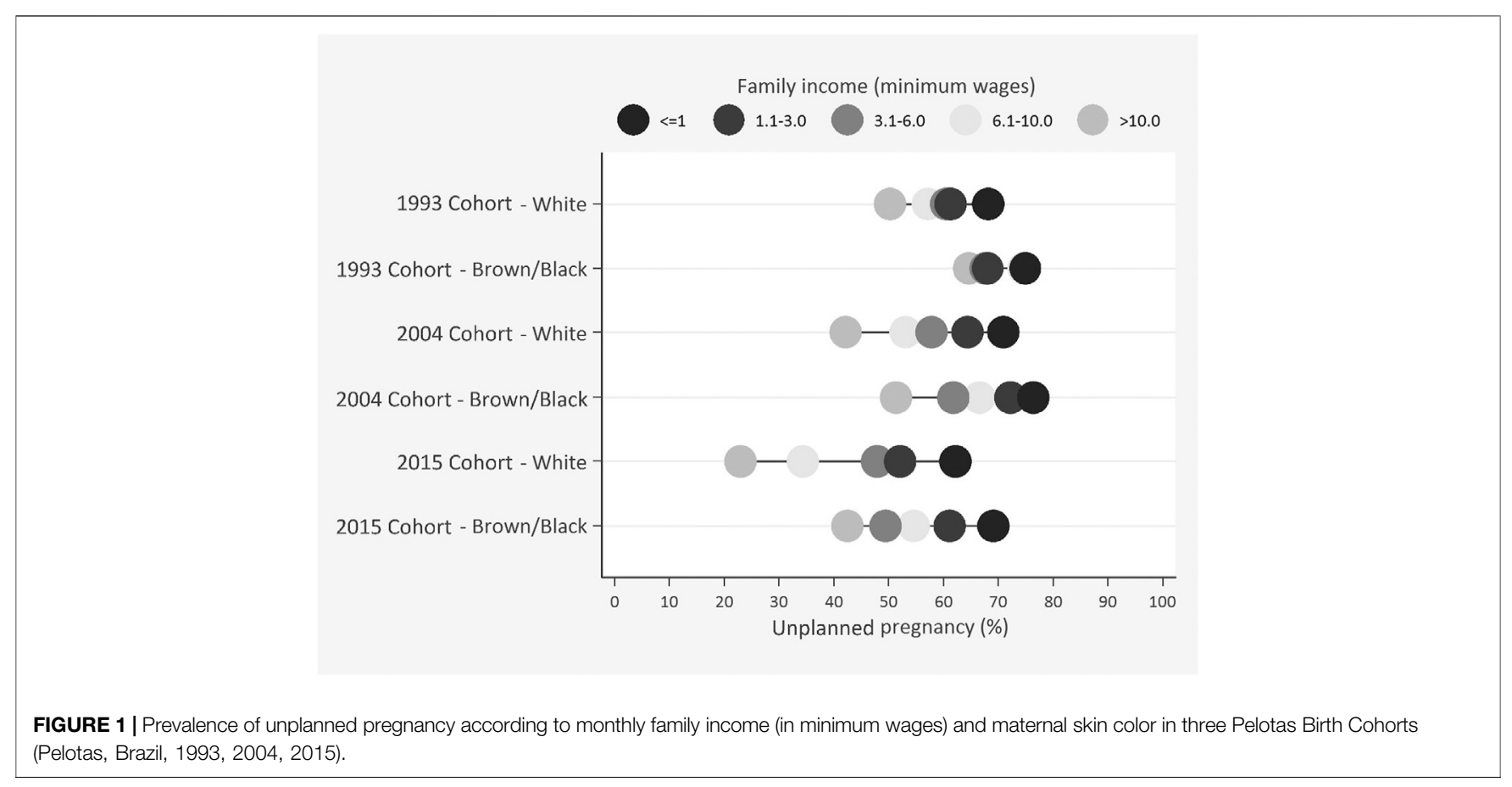

